\title{
ALIH KODE DAN CAMPUR KODE DALAM BERTUTUR MAHASISWA FAKULTAS KEGURUAN DAN ILMU PENDIDIKAN UNIVERSITAS MALIKUSSALEH
}

\author{
oleh \\ Ila Marni, Iba Harliyana*, \& Ririn Rahayu \\ *Dosen Program Studi Pendidikan Bahasa Indonesia, FT Universitas Malikussaleh \\ Surel: iba.harliyana@unima.ac.id
}

\begin{abstract}
ABSTRAK
Penelitian yang berjudul "Alih Kode dan Campur Kode dalam Bertutur Mahasiswa Fakultas Keguruan dan Ilmu Pendidikan Universitas Malikussaleh" ini mengkaji 4 masalah, yaitu (1) bagaimanakah bentuk alih kode yang terjadi dalam tuturan mahasiswa FKIP Universitas Malikussaleh; (2) apa saja faktor yang menyebabkan alih kode yang terjadi dalam tuturan mahasiswa FKIP Universitas Malikussaleh; (3) bagaimanakah bentuk campur kode yang terjadi dalam tuturan mahasiswa FKIP Universitas Malikussaleh; dan (4) apa saja faktor yang menyebabkan campur kode yang terjadi dalam tuturan mahasiswa FKIP Universitas Malikussaleh. Penelitian ini memiliki 4 tujuan, yaitu (1) mendeskripsikan bentuk alih kode dalam tuturan mahasiswa FKIP Universitas Malikussaleh; (2) mendeskripsikan faktor penyebab alih kode dalam tuturan mahasiswa FKIP Universitas Malikussaleh; (3) mendeskripsikan bentuk campur kode dalam bertutur mahasiswa FKIP Universitas Malikussaleh; dan (4) mendeskripsikan faktor penyebab campur kode dalam tuturan mahasiswa FKIP Universitas Malikussaleh. Pendekatan tuturan penelitian ini adalah pendekatan kualitatif. Metode yang digunakan adalah metode deskriptif kualitatif. Data penelitian ini adalah tuturan yang terindikasi alih kode dan campur kode dalam bertutur mahasiswa FKIP Universitas Malikussaleh. Sumber data penelitian ini adalah mahasiswa FKIP Universitas Malikussaleh. Teknik pengumpulan data penelitian ini adalah teknik menyimak, merekam, dan mencatat. Hasil penelitian menemukan adanya alih kode dalam bertutur mahasiswa FKIP Universitas Malikussaleh. Pertama, bentuk alih kode dalam bertutur mahasiswa FKIP Universitas Malikussaleh adalah alih kode intern terdapat 24 data, yaitu 1) alih kode dari bahasa Indonesia ke dalam bahasa Minang terdapat 12 data dan 2) alih kode dari bahasa Indonesia ke dalam bahasa Aceh terdapat 12 data. Alih kode ekstern tidak terdapat dalam bertutur mahasiswa FKIP Universitas Malikussaleh. Faktor penyebab alih kode dalam bertutur mahasiswa FKIP adalah, 1) pembicara atau penutur, 2) pendengar atau mitra tutur, dan 3) berubahnya topik pembicaraan. Kedua, campur kode dalam bertutur mahasiswa FKIP Universitas Malikussaleh terbagi menjadi 3 bentuk yaitu: 1) penyisipan unsur-unsur berwujud kata terdapat 9 data, 2) campur kode penyisipan unsurunsur berwujud frasa terdapat 4 data, dan 3) campur kode penyisipan unsur-unsur berwujud klausa terdapat 4 data. Pada peristiwa campur kode terjadi campur kode ke dalam (inner code-mixing) berupa bahasa daerah yang menyisip pada bahasa pertama yaitu bahasa Indonesia sebanyak 15 data dan campur kode ke luar (outher code-mixing) berupa bahasa asing yang menyisip pada bahasa pertama yaitu bahasa Indonesia sebanyak 2 data. Faktor penyebab campur kode dalam bertutur mahasiswa FKIP Universitas Malikussaleh yaitu: 1)
\end{abstract}


ingin menjelaskan sesuatu dengan maksud tertentu, 2) ingin menjalin keakraban, 3) pengaruh pihak kedua, dan 4) latar belakang sikap penutur.

Kata Kunci: Alih Kode, Campur Kode, Tuturan

\section{PENDAHULUAN}

Manusia merupakan makhluk sosial yang membutuhkan orang lain. Dalam rangka memenuhi segala kebutuhan hidupnya, ia tidak dapat berdiri sendiri tanpa bantuan orang lain. Oleh karena itu, ada hubungan ketergantungan antara manusia yang satu dengan yang lainnya. Hubungan ketergantungan tersebut bisa dalam wujud interaksi dan komunikasi antara sesama manusia. Hal yang dibutuhkan dalam proses interaksi dan komunikasi adalah berupa bahasa.

Bahasa sangat berperan penting dalam kehidupan manusia. bahasa dapat menghubungkan manusia yang satu dengan yang lainnya. Bahasa merupakan sistem lambang bunyi yang bersifat arbitrer (manasuka) yang digunakan oleh anggota suatu masyarakat untuk bekerja sama, berinteraksi, dan juga untuk mengidentifikasi diri (KBBI, 2008:119). Bahasa ialah sistem tanda bunyi yang disepakati untuk dipergunakan oleh anggota kelompok masyarakat tertentu dalam bekerja sama, berkomunikasi, dan mengidentifikasikan diri.

Bahasa itu beragam karena mempunyai kaidah atau pola tertentu yang sama. Bahasa itu digunakan oleh penutur yang heterogen dan mempunyai latar belakang sosial dan kebiasaan berbeda. Kridalaksana (dalam Chaer, 2010:32) menyatakan bahwa bahasa adalah sistem lambang bunyi yang digunakan oleh anggota kelompok sosial untuk bekerja sama, berkomunikasi, dan mengidentifikasikan diri.

Apple (dalam Chaer dan Agustina, 2010:107) menyatakan bahwa alih kode adalah gejala peralihan pemakaian bahasa karena berubahnya situasi. Alih kode sering terjadi dalam percakapan masyarakat multilingual. Alih kode adalah peristiwa peralihan bahasa karena kehadiran orang ketiga atau orang lain yang tidak berlatar belakang bahasa yang sama dengan bahasa yang sedang digunakan oleh penutur dan mitra tutur. Semua itu dilakukan agar percakapan dapat dimengerti, misalnya, penutur menggunakan bahasa Aceh beralih menggunakan bahasa Indonesia. Alih kode merupakan salah satu aspek ketergantungan bahasa dalam masyarakat multilingual. Dalam alih kode masing-masing bahasa cenderung masih mendukung fungsi masing-masing sesuai dengan konteksnya.

Peristiwa alih kode sering diikuti dengan pembicaraan mengenai peristiwa campur kode. Kedua peristiwa tersebut lazim terjadi dalam masyarakat yang bilingual. Peristiwa campur kode terjadi apabila seorang penutur bahasa yang sedang berbahasa Indonesia, kemudian memasukkan unsur-unsur bahasa daerah ataupun unsur-unsur bahasa asing lainnya ke dalam bahasa Indonesia. Campur kode disebabkan oleh keterbatasan bahasa yang dimiliki penutur sehingga menggabungkan bahasa yang digunakannya dengan bahasa lain yang mudah dipahami. Dalam berinteraksi seseorang sering terjadi pemilihan bahasa yang akan digunakan agar bahasa tersebut dapat dipahami dan dimengerti oleh mitra tutur. Peralihan dan penyisipan bahasa lain ke dalam suatu struktur bahasa sering terjadi dalam kehidupan seharihari, seperti di lingkungan kampus, di sekolah, di pasar, di rumah sakit, di lingkungan kerja, media cetak dan elektronik.

Mahasiswa Fakultas Keguruan dan Ilmu Pendidikan (selanjutnya FKIP) 
yang berada di lingkungan Universitas Malikussaleh merupakan penutur dwibahasa. Mahasiswa yang berlatar belakang dan suasana kebahasaan yang tidak sama sering mencampuradukkan bahasa Indonesia dengan bahasa daerah dan bahasa asing dalam berkomunikasi di lingkungan kampus. Penggunaan bahasa yang beragam dapat mengakibatkan munculnya fenomena bahasa berupa alih kode dan campur kode.

Banyaknya suku dan bahasa yang berbeda di antara mahasiswa FKIP Universitas Malikussaleh, peneliti membatasi penelitian alih kode dan campur kode ini hanya pada alih kode dan campur kode dari bahasa Indonesia ke dalam bahasa Aceh, bahasa Indonesia ke dalam bahasa Minang, dan bahasa Indonesia ke dalam bahasa asing. Penelitian ini dibatasi agar penelitian tersebut terarah dan tidak terlalu luas sehingga tujuan penelitian dapat tercapai pada permasalahan yang lebih khusus untuk mendapatkan hasil yang lebih maksimal. Berdasarkan latar belakang masalah di atas peneliti tertarik melakukan penelitian mengenai alih kode dan campur kode ini. Adapun hal yang mendasari peneliti melakukan penelitian ini adalah pertama, penelitian ini belum pernah dilakukan pada Prodi Pendidikan Bahasa Indonesia, Fakultas Keguruan dan Ilmu pendididikan di Universitas Malikussaleh, kedua, mahasiswa FKIP berasal dari berbagai wilayah dengan latar belakang bahasa, suku, dan kebudayaan yang berbeda. Keragaman bahasa dan budaya menyebabkan mahasiswa tetap menggunakan bahasa daerahnya pada ranah tertentu sehingga terjadinya alih kode dan campur kode. Ketiga, faktor lainnya adalah berasal dari situasi kebahasaan yang berbeda-beda. Perbedaan tersebut menimbulkan usaha untuk menemukan kesepakatan pemahaman terhadap pemakaian bahasa sehingga mampu menciptakan pilihan berbahasa atau pemilihan kode bahasa yang disesuaikan dengan situasi hubungan antara mahasiswa. Dengan demikian, fenomena tersebut dapat menyebabkan mahasiswa menjadi dwibahasa atau pengunaan dua bahasa sekaligus secara bergantian. Oleh karena itu, peneliti ingin melakukan penelitian mengenai "Alih Kode dan Campur Kode dalam Bertutur Mahasiswa Fakultas Keguruan dan Ilmu Pendidikan, Universitas Malikussaleh".

\section{LANDASAN TEORITIS Alih Kode}

Alih kode disebabkan oleh beberapa hal, antara lain karena orang yang bersangkutan berlatih menggunakan bahasa tertentu dalam membicarakan suatu pokok pembicaraan tertentu. Apple (dalam Chaer dan Agustin, 2010:40) mengemukakan bahwa alih kode merupakan suatu gejala peralihan bahasa yang melibatkan lebih dari dua bahasa yang digunakan dalam tindak komunikasi. Poejosoedarmo (dalam Nugroho, 49:2010) menyebutkan bahwa alih kode dapat berupa alih varian, alih ragam, alih gaya, atau alih register.

\section{Campur Kode}

Peristiwa campur kode lazim terjadi dalam masyarakat bilingual. Campur kode terjadi apabila seorang penutur menggunakan suatu bahasa secara dominan yang disisipi dengan unsur bahasa lain atau apabila seseorang mencampurkan dua bahasa atau ragam bahasa dalam suatu tindak bahasa. Chaer dan Agustina (2010:114) menyebutkan bahwa peristiwa campur kode terjadi apabila seorang penutur bahasa Indonesia memasukkan unsur-unsur bahasa daerah ataupun memasukkan unsur-unsur bahasa asing ke dalam pembicaraan bahasa Indonesianya tersebut. Dengan kata lain, seseorang yang berbicara dengan kode utama 
bahasa Indonesia yang mempunyai fungsi keotonomiannya, sedangkan kode bahasa daerah atau bahasa asing yang terlibat dalam kode utama tersebut merupakan serpihan-serpihan saja tanpa fungsi atau keotonomian sebagai sebuah kode.

Penelitian mengenai alih kode dan campur kode pernah dilakukan oleh Murniati, dkk. (2015) dengan judul Alih Kode dan Campur Kode pada Mahasiswa PBSI dan Implikasinya, Fakultas Keguruan dan Ilmu Pendidikan Jurusan Bahasa dan Sastra Indonesia Universitas Lampung. Hasil penelitian menunjukkan bahwa terjadi alih kode yaitu alih kode intern sebanyak 41 kali dan alih kode ekstern sebanyak 9 kali selain itu, juga terjadi campur kode yaitu campur kode kata sebanyak 57 kali, frasa sebanyak 25 kali, baster sebanyak 2 kali, dan klausa sebanyak 16 kali.

Penelitian juga pernah dilakukan oleh, Hardianti (2017) dengan judul Campur Kode pada Tuturan Sehari-hari Masyarakat di Desa Kedai Durian Delitua, Fakultas Studi Sastra Indonesia, Universitas Sumatra Utara pada tahun 2017. Hasil dari analisis penelitian yang dilakukan dapat disimpulkan, bahwa 1) bentuk-bentuk campur kode pada tuturan sehari hari masyarakat di Desa Kedai Durian Delitua yaitu: (1) bentuk penyisipan kata, (2). penyisipan frasa, dan penyisipan pengulangan kata. 2) faktor penyebab terjadinya campur kode dalam peristiwa tuturan sehari-hari masyarakat di Desa Kedai Durian Delitua ada tiga macam yaitu: (1) ingin menjelaskan sesuatu/maksud tertentu, (2) karena adanya pihak kedua, dan (3) ingin menjalin keakraban.

\section{METODE PENELITIAN}

Penelitian ini menggunakan pendekatan kualitatif. Hal itu sesuai dengan pendapat Syamsudin dan Damainanti (2011:74) yang menyatakan bahwa pendekatan kualitatif merupakan suatu pendekatan yang dianggap penting untuk memahami suatu fenomena sosial yang diteliti. Tujuan pokoknya adalah untuk menggambarkan, mempelajari, dan menjelaskan fenomena itu sendiri.

Jenis penelitian ini adalah penelitian kualitatif dengan metode deskriptif. Metode deskriptif merupakan mengumpulkan data dan fonomena yang ada di lapangan, kemudian menjelaskannya dengan menggunakan teori yang sudah ada sebagai pedoman dan pendukung. Data dalam penelitian ini adalah tuturan yang terindikasi alih kode dan campur kode dalam bertutur mahasiswa FKIP Universitas Malikussaleh. Data dalam penelitian ini terbagi menjadi dua yang meliputi data primer dan data sekunder. Data primer merupakan data yang diperoleh langsung dari sumbernya melalui rekaman dan wawancara. Data sekunder dalam penelitian ini adalah data yang diperoleh bukan secara langsung dari sumbernya.

Sumber data adalah asal dari data penelitian itu di peroleh. Dari sumber itu penulis memperoleh data yang diinginkan. Sumber data penelitian ini adalah mahasiswa FKIP Universitas Malikussaleh. Di dalam penelitian ini, peneliti mengambil sampel 30 mahasiswa secara acak yang ada di lingkungan Universitas Malikussaleh untuk diteliti. Pengumpulan data penelitian ini menggunakan teknik observasi dengan pengambilan data primer yang langsung dikumpulkan oleh peneliti dengan teknik menyimak, merekam, dan wawancara. Mahsun (2005:90) menyebutkan pemerolehan data dengan menyimak penggunaan bahasa.

Lebih lanjut, Mahsun (2005:356) menyebutkan bahwa metode simak adalah metode yang digunakan peneliti untuk menyimak pembicaraan yang dituturkan oleh narasumber atau penutur bahasa. Teknik yang digunakan adalah teknik simak bebas libat cakap, teknik 
rekam, dan wawancara. Teknik simak libat cakap adalah peneliti sebagai pengamat penggunaan bahasa dengan mendengarkan apa yang dikatakan oleh mahasiswa dalam proses berdialog. Teknik rekam adalah teknik yang digunakan untuk memperoleh data dengan cara merekam tuturan mahasiswa yang sedang berdialog. Teknik wawancara merupakan suatu kegiatan yang dilakukan langsung oleh peneliti dan mengharuskan antara peneliti serta narasumber bertatap muka sehingga dapat melakukan tanya jawab secara langsung dengan menggunakan pedoman wawancara. Penelitian ini dilakukan selama 3 minggu pada tanggal 22 Oktober sampai 12 November. Adapun langkah-langkah yang dilakukan dalam pengumpulan data penelitian ini dengan merekam dan menyimak percakapan yang terjadi dalam tindak komunikasi mahasiswa FKIP Universitas Malikussaleh.

Dalam penelitian ini, analisis data dilakukan dengan analisis kualitatif. Analisis kualitatif yaitu data yang dianalisis bukan data berupa angkaangka, tetapi berupa tuturan. Moleong (2004:280-281) menyebutkan bahwa analisis data adalah proses mengorganisasikan dan mengurutkan data kedalam pola, kategori, dan satuan uraian dasar sehingga dapat ditemukan tema dan tempat dirumuskan hipotesis kerja seperti yang disarankan oleh data. Berikut adalah langkah-langkah yang penulis lakukan dalam menganalisis data penelitian ini.

\section{HASIL PENELITIAN}

\section{Bentuk Alih Kode dalam Bertutur Mahasiwa FKIP Universitas Malikussaleh}

Alih kode (code switching) adalah peristiwa peralihan dari satu kode ke kode yang lain. Misalnya, penutur menggunakan bahasa Indonesia beralih menggunakan bahasa Aceh. Fishman dalam (Chaer dan Agustina, 2010:108) menyebutkan bahwa konteks berbahasa dapat memengaruhi seseorang beralih kode, tergantung pada siapa berbicara, dengan bahasa apa, kepada siapa, kapan, dan dengan tujuan apa.

\section{Alih Kode Intern}

1) Alih Kode Bahasa Indonesia ke dalam Bahasa Minang

Data (1)

$\begin{array}{ll}\text { Konteks } & \begin{array}{l}\text { : } \\ \text { walpaper handphone } \\ \text { Latar belakang }:\end{array} \\ & \text { Ruangan kampus FKIP } \\ & \text { Universitas } \\ & \text { Malikussaleh } \\ \text { Para pembicara : } & \text { Mahasiswa A dan B } \\ & \text { merupakan orang } \\ & \text { Minang dan } \\ & \text { mahasiswa C } \\ & \text { merpakan orang Aceh } \\ & \text { yang tidak bisa } \\ & \text { berbahasa Minang. } \\ : & \text { Walpaper handphone } \\ \text { menggunakan kata- } \\ \text { kata }\end{array}$

Sebab alih kode: Pembicara atau penutur

A : Apa ini A, wallpaper hp ya?

B : Iya.

A : Sakik mato caliak tulisan mode tu lah (sakit mata lihat tulisan-tulisan seperti itu).

B : Baok kasiko, iko kato-kato mutiara mode Mario Teguh (bawa ke sini itu kata-kata mutiara seperti Mario Teguh)

C : Coba lihat, kok ada tulisan-tulisan

Data (1) menunjukkan bahwa peristiwa tutur yang terjadi di lingkungan FKIP Universitas Malikussaleh dengan situasi tutur nonformal. Waktu berlangsungnya peristiwa tutur adalah 23 Oktober 2019. Mahasiswa yang terlibat dalam percakapan adalah mahasiswa FKIP Universitas Malikussaleh. Bentuk peristiwa tutur adalah dialog 
(percakapan).

Pada percakapan mahasiswa FKIP di atas, terjadi alih kode pada percakapan si A. Tuturan di atas membahas mengenai walpaper handphone. Awalnya percakapan menggunakan bahasa Indonesia, kemudian si A mengalihkan kode bahasa yang digunakannya ke dalam bahasa Minang yang berbunyi "baok kasiko, iko katokato mutiara mode Mario Teguh" dalam bahasa Indonesia berarti "bawa sini, itu kata-kata mutiara kayak Mario Teguh". Adapun bentuk alih kode yang terjadi yaitu alih kode intern dari bahasa Indonesia ke bahasa Minang yang berwujud kalimat.

2) Alih Kode Bahasa Indonesia ke dalam Bahasa Aceh

Data (13)

$\begin{array}{ll}\text { Konteks } & \begin{array}{l}\text { : Percakapan } \\ \text { antarsesama } \\ \text { mahasiswa mengenai }\end{array} \\ \text { seminar. } \\ \text { Latar belakang } & \text { : Lingkungan FKIP } \\ & \text { Universitas } \\ & \text { Malikussaleh } \\ \text { Para pembicara } & \text { : Mahasiswa B dan C } \\ & \text { merupakan orang } \\ & \text { Aceh dan mahasiswa } \\ & \text { A merupakan orang } \\ & \text { Minang yang tidak } \\ & \text { bisa berbahasa Aceh. } \\ & \text { : Seminar proposal } \\ \text { Topik } & \text { Pendengar atau mitra } \\ \text { tutur }\end{array}$

A : Budah seminar, kan?

B : Belum.

A : Gohlom seminar, kôp trép awak droeneuh 'eu?' (belum seminar, kok lama kalian ya?)

B : Hana trép hai, mantöng semester lapan mantöng lam kategori (tidak lamalah, masih semester delapan masih dalam kategori)
Data (13) menunjukkan bahwa peristiwa tutur yang terjadi di lingkungan FKIP Universitas Malikussaleh dengan situasi tutur nonformal. Waktu berlangsungnya peristiwa tutur adalah 22 Oktober 2019. Mahasiswa yang terlibat dalam percakapan adalah mahasiswa FKIP Universitas Malikussaleh. Bentuk peristiwa tutur adalah dialog (percakapan).

Pada percakapan mahasiswa FKIP di atas, terjadi alih kode pada percakapan si B. Pada tuturan diatas percakapan mengenai seminar. Awalnya percakapan menggunakan bahasa Indonesia, kemudian si B mengalihkan kode bahasa ke dalam bahasa Aceh yaitu "hana trép hai, mantöng semester lapan mantöng lam kategori " dalam bahasa Indonesia berarti "ngak lama eh, masih semester 8 , masih dalam kategori". Adapun bentuk alih kode yang terjadi adalah alih kode intern. Alih kode yang terjadi yaitu dari bahasa bahasa Indonesia ke bahasa Aceh yang berwujud kalimat.

\section{Alih Kode Ekstern}

Soewito (dalam Chaer dan Agustina, 2010:114) menyatakan bahwa alih kode ekstern adalah alih kode yang berlangsung antara bahasa penutur dengan bahasa asing atau bahasa yang tidak serumpun, seperti dari bahasa Indonesia ke bahasa Inggris atau sebaliknya. Berdasarkan analisis yang telah peneliti lakukan dalam bertutur mahasiswa Fakultas Keguruan dan Ilmu Pendidikan Universitas Malikussaleh hanya terdapat alih kode intern. Alih kode ekstern tidak terdapat dalam bertutur mahasiswa Fakultas Keguruan dan Ilmu Pendidikan Universitas Malikussaleh.

\section{Faktor Penyebab Alih Kode dalam tuturan mahasiswa FKIP di Universitas Malikussaleh}

Alih kode terjadi pada mahasiswa dwibahasawan atau penggunaan bahasa 
secara bergantian. Selain menguasai bahasa Indonesia, mahasiswa juga menguasai bahasa ibu (bahasa pertama) dalam berkomunukasi. Pada tuturan mahasiswa FKIP di Universitas Malikussaleh terjadi alih kode dari bahasa Indonesia ke dalam bahasa Minang dan alih kode dari bahasa Indonesia ke dalam bahasa Aceh. Alih kode tersebut dapat terjadi saat berkomunikasi yang bersifat nonformal, perubahan situasi bicara, dan tempat di mana penutur. Dengan demikian, alih kode terjadi karena dilatarbelakangi oleh berbagai alasan atau sebab. Chaer dan Agustina (2010:108) mengemukakan bahwa penyebab terjadinya alih kode sebagai berikut.

1) Pembicara atau penutur

2) Pendengar atau lawan tutur

3) Perubahan situasi dengan hadirnya orang ketiga

4) Perubahan dari formal ke informal

5) Perubahan topik pembicaraan

Namun, dalam penelitian ini hanya ditemukan faktor-faktor yang menyebabkan terjadinya alih kode pada tuturan mahasiswa FKIP di Universitas Malikussaleh sebagai berikut.

1) Pembicara atau penutur

2) Pendengar atau mitra tutur,

3) Berubahnya topik pembicaraan

1) Pembicara atau penutur

Faktor penyebab terjadinya alih kode pada tuturan mahasiswa FKIP di Universitas Malikussaleh adalah pembicara atau penutur.

Data (1)

$\begin{array}{ll}\text { Konteks } & \begin{array}{l}\text { Percakapan mengenai } \\ \text { walpaper handphone }\end{array} \\ \text { Latar belakang }: & \text { Ruangan kampus FKIP } \\ & \text { Universitas } \\ & \text { Malikussaleh } \\ \text { Para pembicara : } & \text { Mahasiswa A dan B } \\ & \text { merupakan orang } \\ & \text { Minang dan } \\ & \text { mahasiswa C }\end{array}$

merpakan orang Aceh

yang tidak bisa

berbahasa Minang.

Topik

: Walpaper handphone menggunakan katakata

Sebab alih kode: Pembicara atau penutur

A : Apa ini A, wallpaper hp ya?

B : Iya.

A : Sakik mato caliak tulisan mode tu lah (sakit mata lihat tulisan-tulisan seperti itu).

B : Baok kasiko, itu kato-kato mutiara mode Mario Teguh (bawa ke sini itu kata-kata mutiara seperti Mario Teguh)

A : Coba lihat, kok ada tulisan-tulisan

Data (1) menunjukkan bahwa peristiwa tutur yang terjadi di lingkungan FKIP Universitas Malikussaleh dengan situasi tutur nonformal. Waktu berlangsungnya peristiwa tutur adalah 23 Oktober 2019. Mahasiswa yang terlibat dalam percakapan adalah mahasiswa FKIP Universitas Malikussaleh. Bentuk peristiwa tutur adalah dialog (percakapan).

Pada percakapan mahasiswa FKIP di atas, terjadi alih kode pada percakapan si A. Tuturan di atas membahas mengenai walpaper handphone. Awalnya percakapan menggunakan bahasa Indonesia, kemudian si A mengalihkan kode bahasa yang digunakannya ke dalam bahasa Minang yang berbunyi "baok kasiko, itu katokato mutiara mode Mario Teguh." dalam bahasa Indonesia berarti "bawa sini, itu kata-kata mutiara kayak Mario Teguh". Adapun penyebab terjadinya alih adalah pembicara atau penutur merupakan penutur bahasa yang sama dengan mitra tutur. Hal itu dapat dilihat pada percakapan mitra tutur yang dengan fasih menggunakan bahasa Minang dalam berkomunikasi. Pembicara atau penutur 
melakukan alih kode dengan maksud mengimbangi kemampuan bahasa mitra tutur.

2) Pendengar atau mitra tutur

Faktor penyebab terjadinya alih kode pada tuturan mahasiswa FKIP di Universitas Malikussaleh adalah pendengar atau mitra tutur.

Data (3)

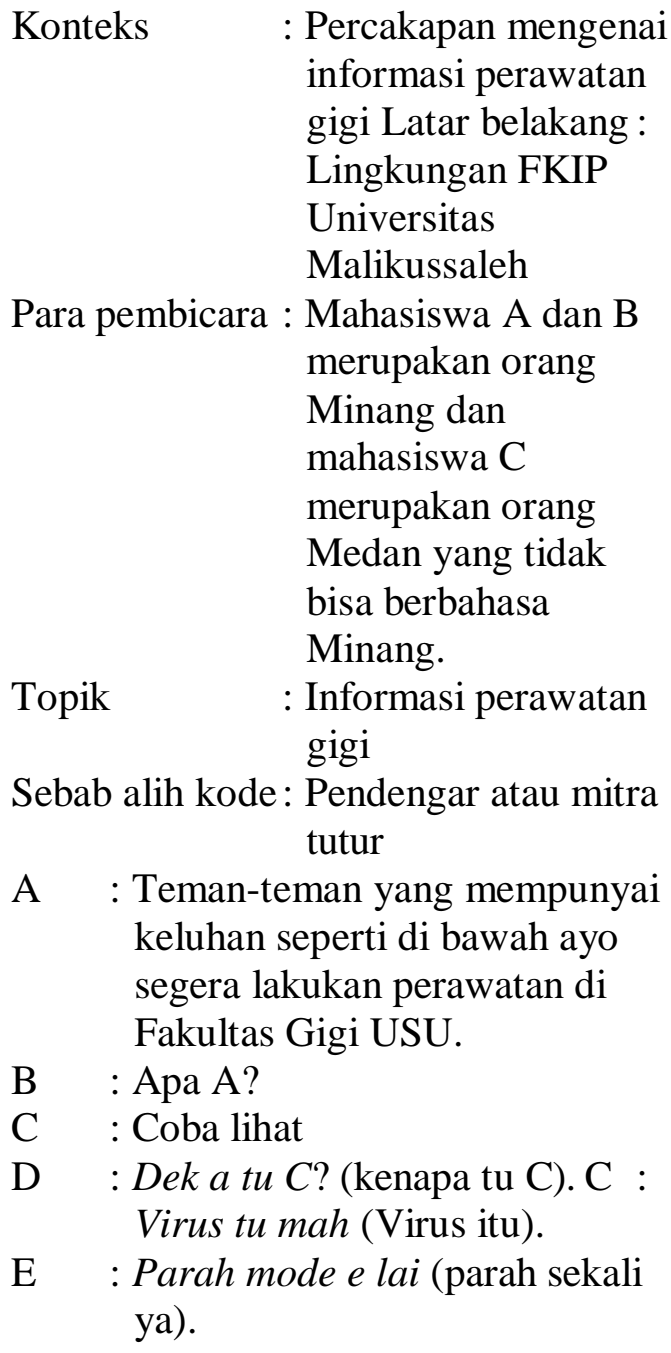

Data (3) menunjukkan bahwa peristiwa tutur yang terjadi di lingkungan FKIP Universitas Malikussaleh dengan situasi tutur nonformal. Waktu berlangsungnya peristiwa tutur adalah 24 Oktober 2019. Mahasiswa yang terlibat dalam percakapan adalah mahasiswa FKIP Universitas Malikussaleh. Bentuk peristiwa tutur adalah dialog (percakapan).

Pada percakapan mahasiswa FKIP di atas terjadi alih kode pada percakapan si B. Tuturan di atas membahas mengenai informasi perawatan gigi. Pada awal percakapan menggunakan bahasa Indonesia, kemudian di tengah percakapan si B beralih kode dari bahasa Indonesia ke dalam bahasa Minang. Alih kode tersebut berbunyi "Dek a tu C?" dalam bahasa Indonesia "kenapa tu C?". adapun penyebab terjadinya alih kode ini adalah pendengar atau mitra tutur. Pada tuturan di atas penutur beralih kode ke dalam bahasa Minang untuk menyesuaikan kode bahasa yang digunakan mitra tutur agar maksud yang ingin disampaikan dapat dipahami dengan baik.

3) Berubahnya topik pembicaraan Faktor penyebab terjadinya alih kode pada tuturan mahasiswa FKIP di Universitas Malikussaleh adalah berubahnya topik pembicaraan.

Data (24)

$\begin{array}{ll}\text { Konteks } & \begin{array}{l}\text { : } \\ \text { Percakapan mengenai } \\ \text { belajar bahasa Aceh }\end{array} \\ \text { Latar belakang }: & \text { Lingkungan FKIP } \\ & \text { Universitas } \\ & \text { Malikussaleh } \\ \text { Para pembicara }: & \text { Mahasiswa A dan B } \\ & \text { merupakan orang Aceh, } \\ & \text { mahasiswa C } \\ & \text { merupakan orang } \\ & \text { Minang dan D } \\ & \text { merupakan orang } \\ & \text { Medan yang tidak bisa } \\ & \text { berbahasa Aceh. } \\ : \text { Pergi ke Banda Aceh } & \\ \text { Topik } & \text { Berubahnya topic } \\ \text { pebab alih kode } & \text { pembicaran }\end{array}$

A : D belajar bahasa Aceh, tengok kakak tu pantang menyerah.

B : C udah mau menyerah dia, kan?

A : Udah mau menyerah belum semester akhir. 
D : Belum

B : Menyerah bahasa Aceh

A : Tebal ini B, jepitnya kok kecil.

B : Kapeurayek ju (kamu besarkan saja)

A : Kiban ku peurayek? (bagaimana saya besarkan?)

\section{Bentuk Campur Kode dalam Bertutur Mahasiswa FKIP Universitas Malikussaleh}

Campur kode (code-mixing) terjadi apabila seorang penutur menggunakan suatu bahasa secara dominan yang mendukung suatu tuturan dan disisipi unsur bahasa lain. Hal ini biasanya berhubungan dengan karakteristik penutur, seperti latar belakang sosial, tingkat pendidikan, dan kebahasaan. Biasanya ciri menonjolnya berupa kesantaian atau situasi informal. Namun biasa juga terjadi karena keterbatasan bahasa, ungkapan dalam bahasa tersebut tidak ada padanannya, sehingga ada keterpaksaan menggunakan bahasa lain.

1. Campur kode berupa penyisipan unsur-unsur berwujud kata

2. Campur kode berupa penyisipan unsur-unsur berwujud frasa

3. Campur kode berupa penyisipan unsur-unsur berwujud klausa

\section{Faktor-Faktor Penyebab Terjadinya Campur Kode Dalam Peristiwa Tuturan Antar Mahasiswa}

Ada beberapa faktor yang melatarbelakangi terjadinya campur kode pada tuturan mahasiswa Fakultas Keguruan dan Ilmu Pendidikan di lingkungan Universitas Malikussaleh. Penyebab mahasiswa melakukan campur kode memiliki maksud dan sebab- sebab tertentu. Adapun maksud dan sebabsebab tersebut adalah sebagai berikut:

1. Ingin menjelaskan sesuatu dengan maksud tertentu

2. Ingin menjalin keakraban

3. Adanya pengaruh pihak kedua

\section{Latar belakang penutur}

\section{PEMBAHASAN}

Penelitian ini telah menelaah tuturan mahasiswa di lingkungan FKIP Universitas Malikussaleh. Tuturan yang ditelaah yakni alih kode dan campur kode dalam bertutur mahasiwa. Peneliti juga menelaah faktor penyebab alih kode dan campur kode dalam bertutur mahasiswa Fakultas Keguruan dan Ilmu Pendidikan Universitas Malikussaleh.

Unsur pertama yang peneliti telaah mengenai alih kode. Berdasarkan hasil penelitian, peneliti menemukan adanya alih kode dalam bertutur mahasiswa Fakultas Keguruan dan Ilmu Pendidikan Universitas Malikussaleh. Alih kode tersebut berupa alih kode dari bahasa Indonesia ke dalam bahasa Minang dan alih kode dari bahasa Indonesia ke dalam bahasa Aceh. Alih kode dilakukan oleh dua pihak yang memiliki dua komunitas bahasa yang sama. Alih kode juga terjadi pada peralihan pemakaian bahasa karena berubah situasi. Hal tersebut sesuai dengan pendapat Apple dalam (Chaer dan Agustin, 2010:40) mengemukakan bahwa alih kode merupakan suatu gejala peralihan bahasa yang melibatkan lebih dari dua bahasa yang digunakan dalam tindak komunikasi. Sedangkan menurut Kridalaksana (dalam Costa) menyatakan bahwa alih kode (code switching) adalah penggunaan variasi bahasa lain atau bahasa lain dalam satu peristiwa bahasa sebagai strategi untuk menyesuaikan diri dengan peran atau situasi lain, atau karena adanya pertisipan lain.

Berdasarkan analisis yang telah peneliti lakukan dalam bertutur mahasiswa Fakultas Keguruan dan Ilmu Pendidikan Universitas Malikussaleh, hanya terdapat alih kode intern. Alih kode ekstern tidak terdapat dalam bertutur mahasiswa Fakultas Keguruan dan Ilmu Pendidikan Universitas Malikussaleh. Alih kode intern terdapat 24 data yaitu, alih kode dari bahasa 
Indonesia ke dalam bahasa Minang terdapat 12 data dan alih kode dari bahasa Indonesia ke dalam bahasa Aceh terdapat 12 data. Alih kode disebabkan karena orang yang bersangkutan berlatih menggunakan bahasa tertentu dalam membicarakan suatu pokok pembicaraan tertentu atau dengan maksud tertentu. Berdasarkan hasil analisis, peneliti menemukan faktor penyebab alih kode dalam bertutur mahasiswa Fakultas Keguruan dan Ilmu Pendidikan yaitu, pembicara atau penutur, pendengar atau mitra tutur, dan berubahnya topik pembicaraan.

Unsur kedua yang ditelaah oleh peneliti adalah campur kode dalam bertutur mahasiswa Fakultas Keguruan dan Ilmu Pendidikan Universitas Malikussaleh. Campur kode tersebut berupa penyisipan unsur-unsur berwujud kata terdapat 9 data, campur kode penyisipan unsur-unsur berwujud frasa terdapat 4 data, dan campur kode penyisipan unsur- unsur berwujud klausa terdapat 4 data. Berdasarkan analisis yang telah peneliti lakukan dalam bertutur mahasiswa Fakultas Keguruan dan Ilmu Pendidikan Universitas Malikussaleh terdapat campur kode ke luar (outer code-mixing) terdapat 2 data dan Campur kode ke dalam (inner codemixing) terdapat 15 data.

\section{PENUTUP}

Berdasarkan analisis data alih kode dan campur kode dalam bertutur mahasiswa Fakultas Keguruan Dan Ilmu Pendidikan Universitas Malikussaleh maka dapat disimpulkan sebagai berikut: Pertama, bentuk alih kode dalam bertutur mahasiswa Fakultas Keguruan Dan Ilmu Pendidikan Universitas Malikussaleh adalah alih kode intern terdapat 24 data, yaitu: 1) alih kode dari bahasa Indonesia ke dalam bahasa Minang terdapat 12 data, dan 2) alih kode dari bahasa Indonesia ke dalam bahasa Aceh terdapat 12 data. Faktor penyebab dalam bertutur mahasiswa FKIP Universitas Malikussaleh adalah sebagai berikut: 1) pembicara atau penutur, 2) pendengar atau mitra tutur, dan 3) Berubahnya topik pembicaraan.

Kedua, bentuk campur kode dalam bertutur mahasiswa FKIP Universitas Malikussaleh terbagi menjadi 3 bentuk yaitu: 1) penyisipan unsur-unsur berwujud kata terdapat 9 data, 2) campur kode penyisipan unsur-unsur berwujud frasa terdapat 4 data, dan

3) campur kode penyisipan unsur-unsur berwujud klausa terdapat 4 data. Pada peristiwa campur kode terjadi campur kode ke dalam (inner code-mixing) berupa bahasa daerah yang menyisip pada bahasa pertama yaitu bahasa Indonesia sebanyak 15 data dan campur kode ke luar (outher code-mixing) berupa bahasa asing yang menyisip pada bahasa pertama yaitu bahasa Indonesia sebanyak 2 data. Faktor penyebab campur kode dalam bertutur mahasiswa FKIP Universitas Malikussaleh yaitu: 1) ingin menjelaskan sesuatu dengan maksud tertentu, 2) ingin menjalin keakraban, 3) pengaruh pihak kedua, dan 4) latar belakang sikap penutur.

Berkenaan dengan penelitian alih kode dan campur kode dalam bertutur mahasiswa FKIP Universitas Malikussaleh perlu dilakukan penelitian lanjutan dengan memperluas bidang cakupannya. Hal ini dimaksudkan agar penelitian selanjutnya tidak hanya membahas bentuk dan faktor saja, tetapi juga membahas masalah lain yang mungkin dapat terjadi dalam peristiwa alih kode dan campur kode. Dengan demikian, peneliti mengharapkan semoga hasil penelitian ini berguna bagi setiap pembaca yang ingin memperdalam penelitiannya dalam penelitian bahasa khususnya tentang alih kode dan campur kode dan dapat menjadi referensi bagi mahasiswa/I yang akan mengadakan penelitian sejenis. 
DAFTAR PUSTAKA

AR, Syamsudin dan Damaianti. 2011. Metode Penelitian Pendidikan Bahasa. Bandung: Remaja Roskadarya.

Aslinda dan Leni Syafyahya. 2014. Pengantar Sosiolinguistik. Bandung: Refika Aditama. Chaer, Abdul dan Leonie Agustina. 2010. Sosiolinguistik: Perkenalan Awal. Jakarta: Rineka Cipta.

Chaer, Abdul. 2003. Linguitik Umum. Jakarta: Rineka Cipta.

Costa, R,F. 2017. "Alih Kode dan Campur Kode Pada Gelar Wicara Hitam Putih dan Implikasinya Terhadap Pembelajaran Bahasa Indonesia di Sekolah Menengah Atas". Skripsi (Internet), (http://digilib.unila.ac.id/25890/1 6/SKRIPSI\%20BAB\%20PEMB AHASAN.pdf) diakses tanggal 28 Maret 2019.

Departemen Pendidikan Nasional. 2008. Kamus Besar Bahasa Indonesia $(K B B I)$. Jakarta: Gramedia Utama.

Kushartanti, Untung, Yuwono dan RMT Lunder, Multamia. 2005. Pesona Bahasa: Langkah Awal Memahami Linguistik. Jakarta: Gramedia Pustaka Utama.

Kridalakasan, Harimurti. 2008. Kamus Linguistik. Jakarta: Gramedia Pustaka Utama. Mahsun. 2005. Metode Penelitian Bahasa: Tahapan Strategi, Metode, dan Tekniknya. Jakarta: Raja Grafindo Persada.

Malabar, Sayama. 2015. Sosiolinguitik. Gorontalo: Perpustakaan Nasional RI.
Marni, W,O. 2016. “Campur Kode Dan Alih Kode Dalam Peristiwa Jual Beli Di Pasar Labuan Tabelo Kecamatan Wakorumba Utara Kabupaten Buton Utara". Jurnal (Internet), (http://ojs.uho.ac.id/index.php/B ASTRA/article/download/152/10 85) diakses tanggal 03 Oktober 2019.

Masrudin. 2015. Sosiolinguistik. Sulawesi Selatan: Read Institute Press.

Murniati, dkk. 2015. "Alih Kode Dan Campur Kode Pada Mahasiswa Pbsi Dan Implikasinya” Jurnal (Internet), (http://jurnal.fkip.inila.ac.id/inde x.php.BINDO1/article/viewfile/9 969/6728). diakses 20 Oktober 2019.

Mustikawati, D, A. 2015. Alih Kode Dan Campur Kode Antara Penjual Dan Pembeli (Analisis Pembelajaran Berbahasa Melalui Studi Sosiolinguistik). Jurnal (Internet), (http://journal.umpo.ac.id/index. php/BINDO1/article/viewFile/15 4/141). diakses 03 Oktober 2019.

Nugroho, Adi. 2011. Alih Kode dan Campur Kode Pada Komunikasi Guru-Siswa di SMA NEGERI 1 WONOSARI KLATEN. Jurnal (Internet) (http://eprints.uny.ac.id/21918/1/ Adi\%20Nugroho\%200720424103 9.pdf). diakses tanggal 28 Maret 2019.

Ohoiwutun, Paul. Sosiolinguistik: Memahami Bahasa dalam Konteks Mayarakat Dan Kebudayaan. Bekasi TimurIndonesia: Kesain Blane.

Rosmawati, 2017. Alih Kode Dan Campur Kode Dalam Percakapan 
Di Pasar Batu 12 Kecamatan Cot Girek, Kabupaten Aceh Utara Kajian Sosiolinguistik. Skripsi (Internet), (http://repository.usu.ac.id/handl e/123456789/68721). diakses tanggal 03 Juli 2019.

Sari, D,P. 2017 Alih Kode Dan Campur Kode Masyarakat Kelurahan Sukajawa Bandar Lampung Dan Implikasinya. Jurnal (Internet), (http://jurnal.fkip.unila.ac.id/inde x.php/BINDO1/article/download /13049/9332). diakses tanggal 03 Oktober 2019.

Setyaningrum, K,D,A. 2019. Jenis, Bentuk, Dan Faktor Penyebab Campur Kode Dalam Perbincangan Pengisi Acara "Ini Talk Show" Di Net TV. Skripsi (Internet), (http://repository.usd.ac.id/index.p hp/BINDO1/article/download/141 224008_full.p df). diakses tanggal 23 Oktober 2019.
Syahriandi dan Radhiah. 2019. Terampil Menulis Ilmiah. Lhokseumawe: Sefa Bumi Persada.

Sumarsono dan Pratana. 2002. Sosiolinguistik. Yokyakarta: SABDA (Lembaga Studi Agama dan Perdamaian).

Sutrisno, Asep. 2017. Campur Kode Dialek Dalam Tuturan Mahasiswa FKIP Universitas Muhammadiyah

Purwokerto. Skripsi (Internet), (http://jurnal.fkip.ump.ac.id/inde x.php/BINDO1/article/download /babII_ASEPSUT RISNO_PBSI"16.pdf). diakses tanggal 03 Oktober 2019.

Solechah, Eka. 2016. Alih Kode Dan Campur Kode Pada Tuturan Bahasa Penyiar Dan Pendengar Radio Di Cirebon. Jurnal (Internet), (http://journal.student.uny.ac.id/ ojs/index.php/bsi/article/downloa d/1860/2651). diakses tanggal 03 Oktober 2019. 